\title{
Analysis of the Success of the Personnel Management Information System at the Purwakarta District Attorney with the Delone and Mclean Method
}

\section{Analisis Kesuksesan Sistem nformasi Manajemen Kepegawaian di Kejaksaan Negeri Purwakarta dengan Metode Delone dan Mclean}

\author{
Devianti Anggraeni \\ Universitas Adhirajasa Reswara Sanjaya \\ Bandung, Indonesia \\ deviantia030@gmail.com \\ Rangga Sanjaya \\ Universitas Adhirajasa Reswara Sanjaya \\ Bandung, Indonesia \\ rangga@ars.ac.id
}

\begin{abstract}
Management information system is an information provider system that is used to support the operating system in the process of returning certain decisions within an institution/organization. The application of technology in government agencies is needed to create an accountable, transparent and trustworthy government. The personnel management information system is a useful application for managing administrative data, based on the Decree of the Attorney General of the Republic of Indonesia Number: KEP-155/J.A/12/1997 concerning the operational organization of the management information system of the Indonesian Attorney General's Office. This study aims to determine the success rate of the personnel management system at the Purwakarta District Attorney's Office using the Delone and McLean information system success model. The variables used in this research are system quality, information quality, service quality and user satisfaction. This research is a type of descriptive analysis research that is used to interpret the data that has been processed quantitatively. Based on the results of the study, there is a successful implementation of the Personnel Management Information System (SIMPEG) using the Delone and Mclean method, the quality of information has a positive and significant impact on user satisfaction of the Personnel Management System (SIMPEG), with a significance value of $0.007<0.05$ and a $t$ value of 2,838 $>$ t table 2,021.
\end{abstract}

Keywords: management information systems, personnel, delone and mclean

\begin{abstract}
Abstrak
Sistem nformasi manajemen adalah suatu sistem penyedia nformasi yang digunakan untuk mendukung sistem operasi dalam proses pengembalian keputusan tertentu dalam suatu lembaga/organisasi. Penerapan teknologi pada nstansi pemerintah sangat dibutuhkan untuk menciptakan pemerintahan yang akuntabel, transparan dan dapat dipercaya. Sistem nformasi manajemen kepegawaian adalah aplikasi yang berguna untuk mengelola data administrasi, berdasarkan pada surat Keputusan Jaksa Agung Republik ndonesia Nomor: KEP-155/J.A/12/1997 tentang pengorganisasian operasional sistem nformasi manajemen Kejaksaan Republik ndonesia. Penelitian ni bertujuan untuk mengetahui seberapa besar tingkat keberhasilan sistem manajemen kepegawaian pada kantor Kejaksaan Negeri Purwakarta dengan menggunakan model kesuksesan sistem nformasi Delone dan Mclean. Variabel yang digunakan pada penelitian ni adalah kualitas sistem, kualitas nformasi, kualitas layanan serta kepuasan pengguna. Penelitian ni merupakan jenis penelitian analisis deskriptif yang digunakan untuk menginterpretasikan data yang telah diolah secara kuantitatif. Berdasarkan hasil penelitian, terdapat kesuksesan implementasi Sistem Informasi Manajemen Kepegawaian (SIMPEG) menggunakan metode Delone dan Mclean, kualitas informasi mempunyai pengaruh positif dan signifikan terhadap kepuasan pengguna Sistem Manajemen Kepegawaian (SIMPEG), dengan nilai signifikansi sebesar $0,007<0,05$ dan nilai t hitung 2,838 > t tabel 2,021.
\end{abstract}

Kata kunci: sistem informasi manajemen, kepegawaian, delone dan mclean 


\section{PENDAHULUAN}

Perkembangan teknologi yang pesat di era digital seperti saat ini menjadikan teknologi sangat dibutuhkan oleh masyarakat dalam kehidupan sehari-hari. Dengan adanya teknologi dapat meningkatkan kinerja dan memungkinkan berbagai kegiatan dapat dilakukan dengan cepat, tepat dan akurat, sehingga dapat meningkatkan produktivitas kerja. Penerapan teknologi pada instansi pemerintah sangat dibutuhkan untuk menciptakan pemerintah yang akuntable, transparan dan dapat dipercaya.

Sistem manajemen kepegawaian (SIMPEG) adalah sistem yang dapat membantu dalam memperoleh informasi mengenai proses pengolahan data-data kepegawaian pada suatu perusahaan maupun instansi yang saling berinteraksi mencapai tujuan yang telat ditetapkan. Tujuan SIMPEG secara umum dalam lingkup pemerintahan adalah untuk mendukung sistem manajemen pegawai yang rasional dan mengembangkan sumber daya manusia di aparatur pemerintahan, mewujudkan data kepegawaian yang mutahir dan terintegrasi, menyediakan informasi pegawai yang lebih akurat untuk memenuhi keperluan perencanaan, pengembangan, kesejarteraan, dan pengendalian pegawai serta untuk membantu efektivitas kinerja di bidang kepegawaian.

Kantor Kejaksaan Negeri Purwakarta adalah salah satu instansi pemerintah yang dalam penerapan sistem informasi manajemen kepegawaiannya menggunakan sistem informasi manajemen kepegawaian berbasis komputer. Akan tetapi dalam penerapannya masih belum dapat berjalan sesuai dengan fungsi dan tujuannya secara ideal. Dalam hal ini menarik untuk dikaji, karena peran sistem informasi dalam organisasi atau instansi memiliki pengaruh penting. Untuk mengetahui seberapa besar tingkat kesuksesan pada SIMPEG, penulis menggunakan metode Delone dan Mclean.

Penelitian yang telah dilakukan sebelumnya, yaitu berfokus pada kesuksesan penerapan sistem Dapodikdasmen di Provinsi Sumatera Selatan dengan studi kasus SMA 118 dan SMK 79 di Kota Palembang. Penelitian ini menunjukan data mengenai kesuksesan penerapan sistem Dapodikdasmen menggunakan model Delone dan Mclean karena memiliki persentase sebesar $79,43 \%$, sehingga penerapan aplikasi sistem dapodikdasmen tersebut dapat dikatakan sukses (Rahayu, 2019).

Tujuan dalam penelitian ni untuk mengetahui seberapa besar tingkat kesuksesan penerapan SIMPEG di kantor Kejaksaan Negeri Purwakarta dengan menggunakan metode Delone dan Mclean. Tingkat kesuksesan akan diukur dari empat faktor yaitu kualitas informasi, kualitas sistem, kualitas layanan, dan kepuasan pengguna

\section{METODE}

Berikut merupakan tahapan yang dilakukan pada penelitian ini yaitu sebagai berikut: 

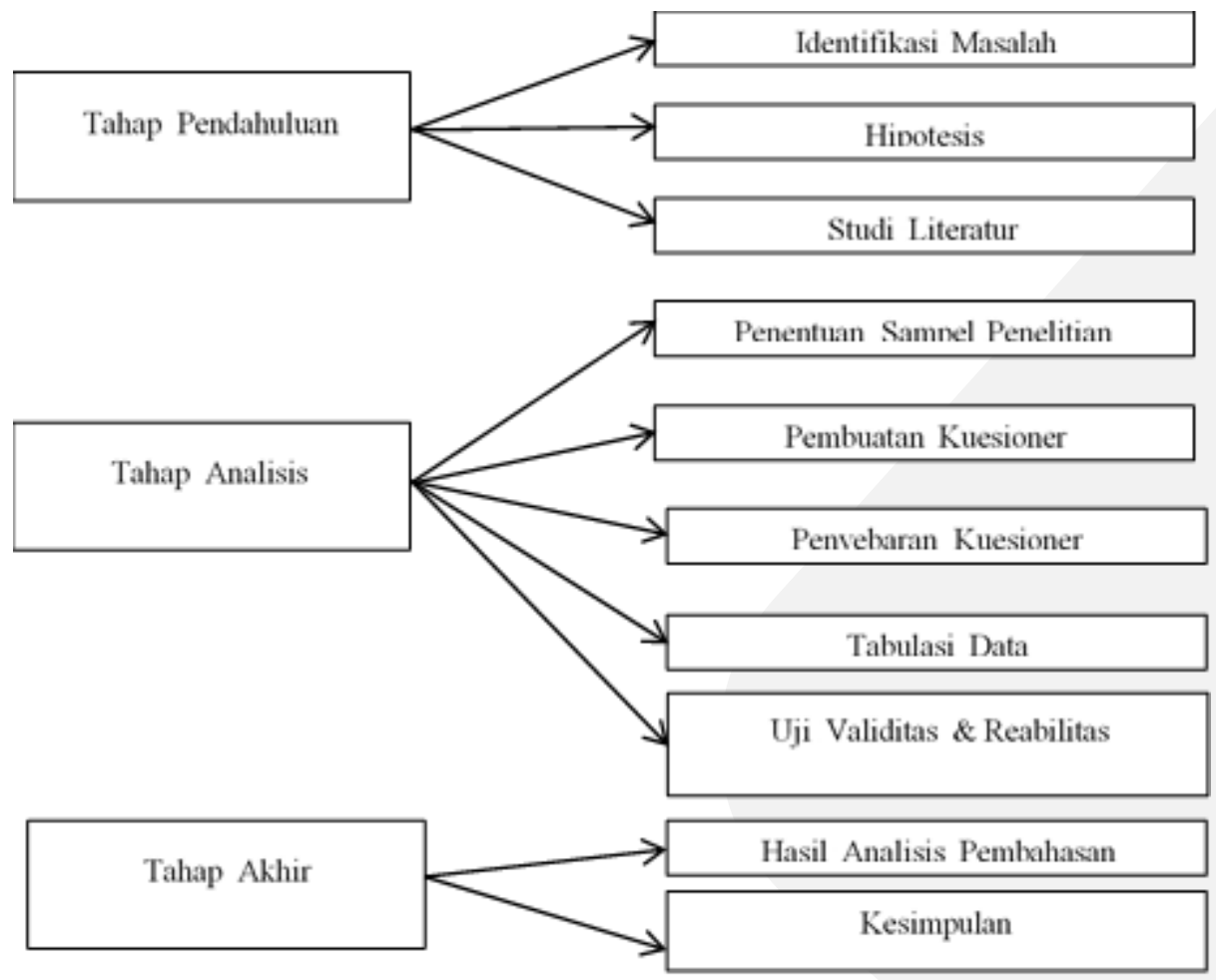

Gambar 1. Desain Penelitian

Populasi yang akan dijadikan sumber pada penelitian ini adalah para pegawai yang ada di Kantor Kejaksaan Negeri Purwakarta dengan jumlah populasi sebanyak 45 orang., seperti yang terdapat pada table di bawah ini:

Tabel 1. Jumlah Pegawai di Kantor Kejaksaan Negeri Purwakarta

\begin{tabular}{ccc}
\hline No. & Pangkat / Golongan & Jumlah Pegawai \\
\hline 1. & Golongan IV./.b & 1 \\
2. & Golongan IV./.a & 7 \\
3. & Golongan III./.d & 6 \\
4. & Golongan III./.c & 4 \\
5. & Golongan III./.b & 12 \\
6. & Golongan III./.a & 5 \\
7. & Golongan II./.c & 3 \\
8. & Golongan II./.d & 1 \\
9. & Golongan II./.b & 1 \\
10. & Golongan II./.a & 5 \\
\hline
\end{tabular}

Sumber: Rekapitulasi Data Pegawai Kejaksaan Negeri Purwakarta (20201)

Kantor Kejaksaan Negeri Purwakarta memiliki jumlah pegawai sebanyak 45 orang, maka jumlah populasi tersebut seluruhnya akan dijadikan responden. Hal tersebut sesuai dengan aturan dalam menentukan besarnya sampel, jika jumlah populasi penelitian kurang dari 100 orang, maka jumlah sampel diambil secara keseluruhan, tetapi jika populasinya lebih besar dari 100 orang, maka dapat diambil antara 10-15\% atau 20 - $25 \%$ dari jumlah populasinya (Sarwono, 2010). Variabel independen adalah variabel yang dapat mempengaruhi timbulnya variabel dependen (Sugiyono, 2017). Variabel independen (variabel bebas) yang digunakan pada penelitian ini terdiri dari kualitas informasi (information quality), kualitas sistem (system quality), dan kualitas layanan (service quality).Variabel dependen adalah variabel yang dipengaruhi atau yang menjadi akibat, karena adanya variabel bebas. Variabel dependen dalam penelitian ini adalah kepuasan pengguna. Instrument yang digunakan pada penelitian.ini.adalah kuesioner. Kuesioner yang dipilih berdasarkan faktor independen yang diteliti yaitu kualitas informasi, kualitas sistem, 
kualitas layanan, dan kepuasan pengguna pada sistem informasi manajemen kepegawaian di Kejaksaan Negeri Purwakarta.

Teknik pengumpulan data yang digunakan pada penelitian ini adalah dengan menggunakan teknik observasi, wawancara, dan kuesioner. Observasi adalah salah satu teknik pengumpulan data dengan cara mengamati, dan memantau secara langsung untuk menemukan permasalahan mengenai suatu kejadian yang terkait dengan peneliti yang akan diteliti (Sanusi, 2011). Dalam hal ini, peneliti mengamati secara langsung aktivitas sistem namajemen kepegawaian yang ada di Kejaksaan Negeri Purwakarta.

Pengumpulan data dalam teknik wawancara ini peneliti menggunakan jenis teknik wawancara semi terstruktur. Pada penelitian ini, disajikan beberapa pernyataan mengenai kesuksesan sistem informasi manajemen kepegawiaan terhadap kepuasan pengguna di Kantor Kejaksaan Negeri Purwakarta. Kuesioner digunakan untuk memperoleh data mengenai variabel penelitian yang diberikan skor menggunakan skala likert. Pada penelitian ini, peneliti menggunakan jawaban setiap item dan penilaian skor sebagai berikut (Andriyanto et al., 2021):

\begin{tabular}{clc} 
Tabel 2. & \multicolumn{2}{c}{ Penilaian Penilaian Skala Likert pada Kuisioner } \\
\hline No. & \multicolumn{1}{c}{ Pilihan Jawaban } & Skor \\
\hline 1. & Sangat Tidak Setuju (STS) & 1 \\
2. & Tidak Setuju (TS) & 2 \\
3. & Netral (N) & 3 \\
4. & Setuju (S) & 4 \\
5. & Sangat Setuju (SS) & 5 \\
\hline
\end{tabular}

\section{HASIL DAN PEMBAHASAN}

\section{Hasil}

Uji validitas digunakan untuk mengukur tingkat-tingkat kesesuaian atau kevalidan ukuran suatu instrument terhadap konsep yang akan diteliti. Instrument dikatakan valid apabila instrument tersebut dapat mengungkap data dari variabel yang diteliti secara tepat (Cholid Narbuko, 2010). Hasil uji validitas dapat dilihat dalam tabel di bawah ini:

\section{Tabel 3. Hasil Uji Validitas}

\begin{tabular}{ccccc}
\hline Variabel & Indikator & R Hitung & R Tabel & Kesimpulan \\
\hline \multirow{3}{*}{ Kualitas Informasi (X1) } & X1.1 & 0,796 & 0,294 & Valid \\
& X1.2 & 0,514 & 0,294 & Valid \\
& X1.3 & 0,702 & 0,294 & Valid \\
& X1.4 & 0,790 & 0,294 & Valid \\
& X2.1 & 0,355 & 0,294 & Valid \\
Kualitas Sistem (X2) & X2.2 & 0,544 & 0,294 & Valid \\
& X2.3 & 0,355 & 0,294 & Valid \\
Kualitas Layanan (X3) & X2.4 & 0,839 & 0,294 & Valid \\
& X2.5 & 0,673 & 0,294 & Valid \\
& X3.1 & 0,831 & 0,294 & Valid \\
Xualitas Kepuasan Pengguna & X3.3 & 0,632 & 0,294 & Valid \\
(X4) & X4.1 & 0,516 & 0,294 & Valid \\
& X4.2 & 0,811 & 0,294 & Valid \\
& X4.3 & 0,825 & 0,294 & Valid \\
& & & & Valid \\
\hline
\end{tabular}


Hasil pada tabel di atas menunjukan bahwa semua item memperoleh nilai korelasi skor item pernyataan untuk masing-masing variabel dengan total skor lebih dari syarat nilai batas ( $\mathrm{r}$ table $=0,294)$. Dengan demikian dapat disimpulkan bahwa item pernyataan seluruh variabel yang digunakan valid sehingga dapat digunakan dalam analisis data selanjutnya.

Pengukuran uji reabilitas digunakan untuk mengukur konsistensi dan instrument penelitian. Suatu variabel dikatakan reliabel jika memberikan nilai Cronbach Alpha $>0.60$ (Ghazali, 2013). Hasil pengujian reliabilitas pada penelitian ini yaitu sebagai berikut:

Tabel 4. Hasil Uji Reabilitas

\begin{tabular}{cccc}
\hline Variabel & $\begin{array}{c}\text { Cronbach's } \\
\text { Alpha }\end{array}$ & $\begin{array}{c}\text { r Tabel Produk } \\
\text { Moment (45) }\end{array}$ & Kesimpulan \\
\hline Kualitas Informasi (X1) & 0,666 & 0.294 & Reliabel \\
Kualitas Sistem (X2) & 0,637 & 0.294 & Reliabel \\
Kualitas Layanan (X3) & 0,645 & 0.294 & Reliabel \\
Kualitas Kepuasan Pengguna (Y) & 0,622 & 0.294 & Reliabel \\
\hline
\end{tabular}

Berdasarkan hasil uji reabilitas dapat diketahui bahwa, semua variabel mempunyai koefisien Cronbach's Alpha yang lebih besar dari $r$ table (0.294), sehingga dapat disimpulkan bahwa seluruh nstrument penelitian dapat dinyatakan reliable.

Uji normalitas bertujuan untuk mengetahui apakah nilai residual berdistribusi normal atau tidak. Uji normalitas juga digunakan sebagai prasyarat dalam analisis product moment (Sugiyono, 2014). Uji normalitas dilakukan dengan statistik Kolmogorov Smirnov terhadap unstandardized residual hasil regresi. Data dikatakan normal apabila nilai probabilitas (sig) Kolmogorov-Smirnov $>0,05$ (Ghazali, 2013). Berikut merupakan hasil uji normalitas menggunakan uji Kolmogorov Smirnov dapat dilihat pada tabel di bawah ini:

Tabel 5. Hasil Uji Kolmogorov-Smirnov One-Sample Kolmogorov-Smirnov Test

\begin{tabular}{llr}
\hline & & Unstandardized Residual \\
Normal Parameters ${ }^{\mathrm{a}, \mathrm{b}}$ & & 45 \\
& Mean & .0000000 \\
Most Extreme Differences & Std. Deviation & 1.39014355 \\
& Absolute & .114 \\
& Positive & .069 \\
Test Statistic & Negative & -.114 \\
Asymp. Sig. (2-tailed) & & .114 \\
& & $.170^{c}$ \\
\hline
\end{tabular}

a. Test distribution is Normal.

b. Calculated from data.

Sumber: Olah Data SPSS

Berdasarkan tabel di atas mengenai hasil pengujian normalitas dengan menggunakan statistik Kolmogorov Smirnov terhadap unstandardized residual hasil regresi dapat disimpulkan bahwa, data yang diperoleh pada variabel X1, X2, X3 menunjukan nilai Asymp.Sig (2-tailed) > 0.05 yaitu mempunyai nilai signifikansi $0.170>0.05$ sehingga dapat dikatakan bahwa data diatas berdistribusi normal karena semua data Asymp,Sig (2-tailed) $>0,05$.

Uji multikolinieritas digunakan untuk mengetahui apakah dalam model regresi terdapat korelasi antar variabel independen (variabel bebas). 
Tabel 6. Hasil Uji Multikolinearitas

\begin{tabular}{lccc}
\hline & & \multicolumn{2}{c}{ Collinearity Statistics } \\
\cline { 3 - 4 } & Model & Tolerance & VIF \\
\hline \multirow{3}{*}{1} & $($ Constant $)$ & & \\
& Kualitas Informasi & 0.821 & 1.218 \\
& Kualitas Sistem & 0.829 & 1.206 \\
& Kualitas Layanan & 0.943 & 1.061 \\
\hline
\end{tabular}

Berdasarkan hasil uji multikolinearitas pada penelitian ini, diketahui bahwa masingmasing variabel independen tersebut mempunyai nilai tolerance $>0.10$ dan pada masing-masing variabel menunjukan nilai VIF $<10$. Sehingga dalam pengujian multikolinieritas tersebut dapat disimpulkan bahwa model bebas dari multikolinearitas.

Uji heteroskedastisitas digunakan untuk menganalisa apakah dalam model regresi terjadi ketidaksamaan variance dari residual satu pengamatan ke pengamatan yang lain (Imam, 2016). Hasil pengujian heteroskedastisitas dengan menggunakan scatterplot dapat dilihat pada tabel sebagai berikut:

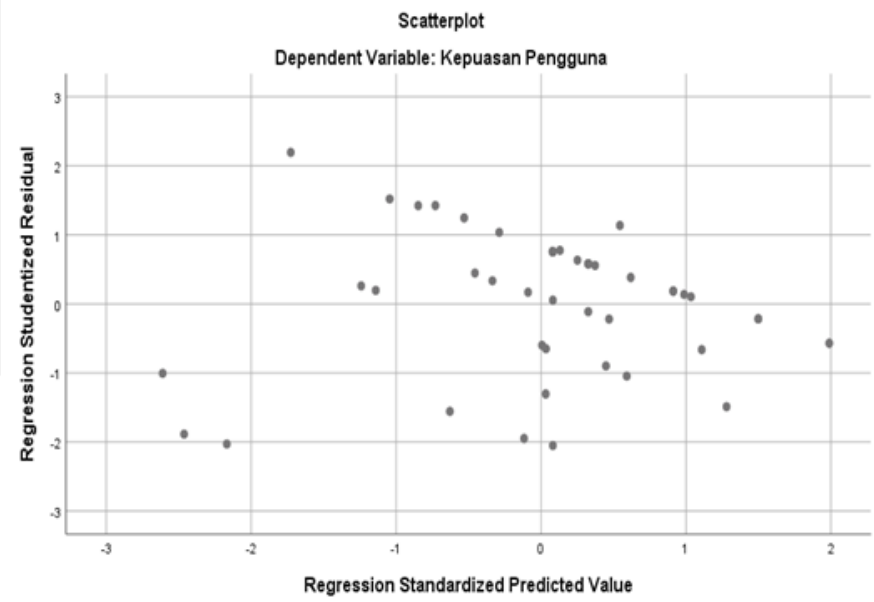

Sumber: olah data SPSS

Gambar 2. Hasil Uji Heteroskedastisitas

Dari pengujian heteroskedastisitas di atas dapat diketahui bahwa, hasil pengujian tersebut sesuai dengan dasar pengambilan keputusan tidak terjadi heteroskedastisitas. Sehingga dapat diperoleh kesimpulan bahwa model yang dihasilkan tidak terjadi heteroskedastisitas.

Uji Autokorelasi digunakan untuk menguji apakah dalam model regresi linear terdapat korelasi antara variabel pengganggu (residual) pada periode $t$ dengan kesalahan pada periode $t-1$ (sebelumnya). Dalam pengujian autokorelasi ini menggunakan model penelitian dengan cara uji Durbin-Watson:

Tabel 7. Hasil Durbin-Watson

\begin{tabular}{cccccc}
\hline Model & $\mathrm{R}$ & R Square & Adjusted R Square & $\begin{array}{c}\text { Std. Error of the } \\
\text { Estimate }\end{array}$ & Durbin-Watson \\
\hline 1 & $.363^{\mathrm{a}}$ & .132 & .066 & 1.32413 & 1.809 \\
\hline
\end{tabular}

a. Predictors: (Constant), LAG_X3, LAG_X1, LAG_X2

b. Dependent Variable: LAG_Y

Sumber : Olah Data SPSS

\begin{tabular}{ccccc}
\hline $\mathrm{d}$ & $\mathrm{Dl}$ & $\mathrm{du}$ & $4-\mathrm{dl}$ & $4-\mathrm{du}$ \\
\hline 1,809 & 1,3832 & 1,6662 & 2,6168 & 2,3338 \\
\hline
\end{tabular}


Pada penelitian ini memperoleh nilai statistik Durbin-Watson sebesar 1,890, sehingga dapat diketahui:

$=\mathrm{Du}<\mathrm{d}<4-\mathrm{dl}$

$=1,6662<1,809<2,3338$

Maka dapat disimpulan bahwa nilai DW tidak terdapat autokorelasi.

Analisis regresi linier berganda adalah model regresi linier yang menjelaskan hubungan satu variabel dependen dengan beberapa variabel independen (Harlan, 2018).

Tabel 8. Hasil Analisis Regresi Linier Berganda

\begin{tabular}{|c|c|c|c|c|c|c|}
\hline \multicolumn{7}{|c|}{ Coefficients $^{a}$} \\
\hline & \multirow[t]{2}{*}{ Model } & \multicolumn{2}{|c|}{ Unstandardized Coefficients } & $\begin{array}{l}\text { Standardized } \\
\text { Coefficients }\end{array}$ & \multirow[t]{2}{*}{$\mathrm{t}$} & \multirow[t]{2}{*}{ Sig. } \\
\hline \multirow{5}{*}{1} & & $\mathrm{~B}$ & Std. Error & Beta & & \\
\hline & (Constant) & .189 & 3.661 & & .052 & .959 \\
\hline & Kualitas Informasi (X1) & .286 & .087 & .445 & 3.278 & .002 \\
\hline & Kualitas Sistem (X2) & .119 & .156 & .102 & .762 & .451 \\
\hline & Kualitas Layanan (X3) & .359 & .223 & .212 & 1.606 & .116 \\
\hline
\end{tabular}

Dependent Variable: Kepuasa Pengguna (Y)

Sumber: olah data SPSS

Analisis regresi linier berganda dilakukan untuk mengetahui ada atau tidaknya pengaruh dua atau lebih variabel bebas $(\mathrm{X})$ terhadap variabel terikat $(\mathrm{Y})$.

Berikut merupakan hasil penelitian mengenai persamaan linier berganda yaitu sebagai berikut:

a. Nilai konstansta kepuasan pengguna (Y) sebesar 0,189 menyatakan jika variabel X1, X2, X3 $=0$, yaitu Kualitas informasi, kualitas sistem, dan kualitas layanan, nilai kepuasan pengguna sebesar 0,189.

b. Koefisien dari X1 sebesar 0,286 bernilai positif, artinya bahwa setiap adanya peningkatan variabel X1 kualitas informasi sebesar $1 \%$.maka kepuasan.pengguna.meningkat sebesar 0,286, begitupun sebaliknya jika adanya penurunan variabel X1 sebesar $1 \%$ maka kepuasan pengguna menurun sebesar 0,286.

c. Koefisien dari X2 sebesar 0,119 bernilai positif, artinya bahwa setiap adanya peningkatan variabel X2 kualitas sistem sebesar 1\% maka kepuasan pengguna meningkat sebesar 0,119, begitupun sebaliknya jika adanya penurunan variabel X2 sebesar $1 \%$ maka kepuasan pengguna menurun sebesar 0,119 .

d. Koefisien dari X3 sebesar 0,359 bernilai positif, artinya bahwa setiap adanya peningkatan variabel X3 kualitas layanan sebesar 1\% maka kepuasan pengguna meningkat sebesar 0,359, begitupun sebaliknya jika adanya penurunan variabel X3 sebesar $1 \%$ maka kepuasan pengguna menurun sebesar 0,359 .

Dengan demikian dapat disimpulkan bahwa variabel X1, X2, dan X3 berpengaruh positif terhadap variabel $\mathrm{Y}$.

Uji T atau uji parsial yaitu untuk mengukur bagaimana pengaruh masing-masing variabel bebas secara sendiri-sendiri terhadap variabel terikat (Hidayat, 2013). Penerimaan atau penolakan hipotesis dilakukan dengan kriteria (Ghazali, 2013):

1. Jika nilai sig $<0,05$ atau $t$ hitung $>\mathrm{t}$ table maka tedapat pengaruh variabel $\mathrm{X}$ terhadap variabel Y.

2. Jika nilai sig $>0,05$ atau $t$ hitung $<\mathrm{t}$ table maka tidak terdapat pengaruh variabel $\mathrm{X}$ terhadap variabel Y

$\mathrm{T}$ tabel $=\mathrm{t}(\mathrm{a} / 2 ; \mathrm{n}-\mathrm{k}-1)$

Keterangan:

$\mathrm{a}=$ Tingkat kepercayaan 0,05

$\mathrm{n}=$ Jumlah sampel

$\mathrm{k}=$ Jumlah variabel independen 
berdasarkan jumlah responden sebanyak 45 orang maka diperoleh hasil sebagai berikut:

$\mathrm{t}$ tabel $=\mathrm{t}(0,05 / 2 ; 45-3-1)$

$$
\begin{aligned}
& =(0,025 ; 41) \\
& =2,020
\end{aligned}
$$

$\mathrm{T}$ tabel untuk 1 sisi $=\mathrm{t}(\mathrm{a} / \mathrm{l} ; \mathrm{n}-\mathrm{k}-1)$

$$
\begin{aligned}
& =(0,05 ; 45-3-1) \\
& =(0,05 ; 41) \\
& =1,683
\end{aligned}
$$

Berikut merupakan hasil dari pengujian hipotesis:

1. Pengujian hipotesis pengaruh kualitas informasi (information quality) terhadap kepuasan pengguna

H0: Kualitas Informasi (Informasi Quality) tidak berpengaruh signifikan terhadap kepuasan pengguna (User Satisfaction).

Ha: Kualitas Informasi (Informasi Quality) berpengaruh signifikan terhadap kepuasan pengguna (User Satisfaction).

Pada output tabel di atas diketahui nilai signifikansi untuk pengaruh X1 terhadap Y adalah sebesar $0,007<0,05$ dan nilai $\mathrm{t}$ hitung 2,838 > t tabel 2,021 sehingga dapat disimpulkan bahwa Ha.di terima, yang berarti terdapat pengaruh X1 terhadap Y.

2. Pengujian hipotesis pengaruh kualitas sistem (system quality) terhadap kepuasan pengguna

H0: Kualitas sistem (System Quality) tidak berpengaruh signifikan terhadap kepuasan pengguna (User Satisfaction).

Ha: Kualitas sistem (System Quality) berpengaruh signifikan terhadap kepuasan pengguna (User Satisfaction).

Diketahui nilai Sig untuk pengaruh X2 terhadap Y adalah sebesar 0,157 $>0,05$ dan nilai t hitung $1,442<2,838$ sehingga dapat disimpulkan bahwa Ha di tolak yang berarti tidak terdapat pengaruh X2 terhadap Y.

3. Pengujian hipotesis pengaruh kualitas layanan (service quality) terhadap kepuasan pengguna

H0: Kualitas layanan (Service Quality) tidak berpengaruh signifikan terhadap kepuasan pengguna (User Satisfaction).

Ha: Kualitas layanan (Service Quality) berpengaruh signifikan terhadap kepuasan pengguna (User Satisfaction).

Diketahui nilai Sig untuk pengaruh X3 terhadap Y adalah sebesar 0,141>0,05 dan nilai $t$ hitung $1,503<\mathrm{t}$ tabel 2,021 sehingga dapat disimpulkan bahwa Ha di tolak yang berarti tidak terdapat pengaruh $\mathrm{X} 3$ terhadap $\mathrm{Y}$.

\section{Pembahasan}

Penelitian ini mengadaptasi teori mengenai tingkat kesuksesan atau keberhasilan suatu sistem informasi yang dikembangkan oleh Delone \& McLean yang sering disebut dengan $D \& M$ Success Model. Dalam penelitian ini peneliti menggunakan beberapa variabel yaitu kualitas sistem, kepuasan pengguna, kualitas informasi dan kualitas layanan. Penelitian ini bertujuan mencari korelasi antar variabel-variabel tersebut. Dari perhitungan responden terhadap item-item pernyataan, menyatakan respon yang baik. Dan berdasarkan hasil pengujian dari hipotesis yang diajukan dalam penelitian ini menunjukan hasil bahwa hipotesis diterima. Dari hasil analisis data tersebut dapat diketahui bahwa, pengaruh kualitas informasi, kualitas sistem, kualitas layanan terhadap sistem manajemen kepegawaian pada kantor Kejaksaan Negeri Purwakarta diperoleh bahwa kualitas informasi mempunyai pengaruh positif dan signifikan terhadap kepuasan pengguna sistem manajemen kepegawaian (SIMPEG). Dengan melihat nilai signifikansi untuk pengaruh $\mathrm{X} 1, \mathrm{X} 2$ dan $\mathrm{X} 3$ secara simultan terhadap Y. Kualitas informasi memiliki nilai Signifikansi untuk pengaruh X1 terhadap $\mathrm{Y}$ adalah sebesar $0,007<0,05$ dan nilai t hitung 2,838 $>\mathrm{t}$ tabel 2,021 sehingga dapat disimpulkan bahwa Ha diterima, yang berarti terdapat pengaruh X1 terhadap Y. Kualitas sistem memiliki nilai Sig untuk pengaruh X2 terhadap Y adalah sebesar $0,157>0,05$ dan nilai t hitung $1,442<2,838$ sehingga dapat disimpulkan bahwa Ha ditolak yang 
berarti tidak terdapat pengaruh.X2.terhadap.Y. dan.untuk.kualitas layanan memiliki nilai Sig untuk pengaruh X3 terhadap $\mathrm{Y}$ adalah sebesar $0,141>0,05$ dan nilai t hitung 1,503 $<\mathrm{t}$ tabel 2,021 sehingga dapat disimpulkan bahwa Ha di tolak yang berarti tidak terdapat pengaruh X3 terhadap Y.

\section{PENUTUP} berikut:

Berikut beberapa kesimpulan yang dapat diambil dalam penelitian ini adalah sebagai

1. Perolehan skor analisis variabel kualitas informasi diperoleh skor total sebesar 600 dengan tingkat persentase $137.2 \%$ dalam kategori cukup baik. Dengan indikator manfaat informasi diperoleh sebesar 199 dengan tingkat persentase 39,8 \%, dalam kategore cukup baik, variabel kelengkapan informasi sebesar $179 \%$ dengan tingkat persentse 35,8\% dalam kategori cukup baik.

2. Perolehan skor analisis variabel kualitas sistem (X2) diperoleh skor total sebesar 874 dengan tingkat persentasi $174,8 \%$ dalam kategori cukup baik. Kemudahan sistem diperoleh sebesar 179 dengan tingkat persentase 35,8 \%, indikator kecepatan sistem diperoleh sebesar 179 dengan tingkat presentase 35,8 \%. Keamanan sistem diperoleh sebesar 161 dengan tingkat presentasi 32,2\%. Dan untuk kesesuai sistem diperoleh sebesar 165 dengan tingkat presentase $33 \%$.

3. Perolehan skor analisis variabel kualitas layanan diperoleh skor total sebesar 516 dengan tingkat persentase 103,2 \%. Indikator kemudahan layanan diperoleh sebesar 183 dengan tingkat presentase 36,6\%, indikator keamanan akses diperoleh sebesar 168 dengan presentasi 336\%. Dan untuk ketepatan layanan diperoleh sebesar 165 dengan tingkat presentase $33 \%$.

4. Perolehan skor analisis variabel kepuasan pengguna (Y) memperoleh skor total sebesar 488 dengan tingkat presentase 97,6\%. Dengan kepuasan pengguna terhadap data dan informasi yang didapat pada sistem diperoleh sebesar 167 dengan tingkat presentase 33,4\%,

5. Nilai pernyataan rata-rata tertinggi untuk variabel kepuasan pengguna yaitu terdapat pada pernyataan, "Pengguna merasa puas dengan data dan informasi yang didapat pada Sistem Informasi Manajemen Kepegawaian (SIMPEG) " yaitu sebesar 33,4 \%. Sedangkan nilai pernyataan rata-rata terendah untuk variabel kualitas sistem yaitu terdapat pada pernyataan," Pengguna akan merekomendasikan Sistem Informasi Manajemen Kepegawaian (SIMPEG) kepada pengguna lainnya" yaitu sebesar $31 \%$.

\section{DAFTAR PUSTAKA}

Andriyanto, D. F., Said, F., Titiani, and Erni. (2021). "Analisis Kesuksesan Apalikasi Jakarta Kini (JAKI) Menggunakan Model Delone dan Mclean," Sist. nf., vol. 23, pp. 45-46.

Narbuko, A. C. (2010). Metodologi Penelitian. Jakarta: Bumi Aksara.

Rahayu, S. (2019). Pengaruh Kesuksesan Sitem Dapodikdasmen Kota Palembang Menggunakan Model Delone Dan Mclean. Sains, Teknol. dan nd., vol. 16, pp. 32-42.

Sanusi, A. (2011). Metode Penelitian Bisnis, 3rd ed. Jakarta: Salemba Empat.

Sarwono, J. (2010). Pintar Menulis Karangan lmiah - Kunci Sukses Dalam Menulis lmiah. Yogyakarta: CV. Andi Offset.

Sugiyono. ((2017). Metode Penelitian, Kuantitatif, Kualitatif, Dan Kombinasi (Mixed Method), 8th ed. Bandung: Alfabeta.

Sugiyono. (2017). Metode Penelitian Kombinasi (Mixed Methods). Bandung: Alfabeta. 